\title{
Correction to: Seismic risk analysis for large dams in West Coast basin, southern Ghana
}

Stephen A. Irinyemi • Domenico Lombardi • Syed M. Ahmad

Published online: 8 November 2021

(C) Springer Nature B.V. 2021

\section{Correction to: Journal of Seismology} https://doi.org/10.1007/s10950-021-10045-w

The original version of the article unfortunately contained a mistake. Authors "Domenico Lombardi" and "Syed M. Ahmad" were inadvertently not included in the author group section. The complete list of authors are reflected above.

The original article has been corrected.

Publisher's note Springer Nature remains neutral with regard to jurisdictional claims in published maps and institutional affiliations.

The online version of the original article can be found at https://doi.org/10.1007/s10950-021-10045-w

S. A. Irinyemi $(\varangle) \cdot$ D. Lombardi $\cdot$ S. M. Ahmad Department of Mechanical, Aerospace and Civil Engineering, University of Manchester,

Manchester M13 9PL, UK

e-mail: stephen.irinyemi@postgrad.manchester.ac.uk 